\title{
Penggunaan Media Peraga Bandul Magnetik Pada Model Pembelajaran Inquiry Untuk Meningkatkan Hasil Belajar Fisika Siswa Kelas XII SMAN 5 Kota Bima
}

\author{
Bambang Setiawan \\ SMAN 5 Kota Bima \\ Email : setyo2008@,yahoo.com
}

\begin{abstract}
ABSTRAK : Penelitian ini dilatarbelakangi oleh tidak optimalnya capaian hasil belajar siswa, khususnya untuk materi-materi yang bersifat abstrak. Ketidakoptimalan hasil belajar ini secara empiris dapat dilihat di sekolah pada umumnya, hal ini disebabkan oleh proses pembelajaran yang masih berpusat pada guru (teacher centre), kurangnya pemanfaatan media belajar sebagai wahana penunjang pembelajaran, dan kurang dilibatkannya siswa dalam mengkonstruksi pengetahuannya sebagai bagian dari pengalaman belajarnya. Untuk mengatasi hal tersebut dalam penelitiannya peneliti memanfaatkan media pembelajaran berupa media peraga bandul magnetik yang diseting pada pembelajaran inquiry dengan harapan terjadinya peningkatan hasil belajar siswa. Atas dasar tersebut maka dalam penelitian ini yang menjadi tujuannya adalah untuk mengetahui peranan penggunaan media alat peraga bandul magnetik pada model pembelajaran Inquiry sehingga dapat meningkatkan hasil belajar Fisika Siswa, selain itu pula dalam penelitian ini juga bertujuan untuk mengetahui respon siswa terhadap penggunaan media peraga bandul magnetik tersebut. Penelitian ini dibatasi pada materi Gaya Lorentz untuk pelajaran Fisika di Kelas XII pada SMAN 5 Kota Bima dengan model penelitian tindakan kelas. Target pencapaian peningkatan hasil belajar adalah $70 \%$ nilai ketuntasan klasikal dengan ketuntasan minimal 65 . Pelaksanaan penelitian berlangsung dalam 2 (dua) siklus dengan perubahan hasil belajar yang bervariasi. Pada siklus I hasil belajar yang dicapai 50 \% nilai ketuntasan klasikalnya dengan rata-rata capaian 60,45, sedangkan pada siklus II hasil belajar yang dicapai $77,3 \%$ nilai ketuntasan klasikalnya dengan rata-rata capaian 66,59. Selain itu dalam penelitian ini didapatkan rata-rata respon siswa terhadap pembelajaran sebesar 72,5 yang artinya memiliki respon yang sangat positif. Dari hasil tersebut dapat disimpulkan bahwa pemanfaatan media peraga bandul magnetik pada model pembelajaran inquiry dapat meningkatkan hasil belajar Fisika siswa kelas XII SMAN 5 Kota Bima, dan siswa memiliki respon sangat positif terhadap proses pembelajaran yang dilakukan.
\end{abstract}

Kata kunci: Bandul Magnetik, Pembelajaran Inquiry, Hasil Belajar

\section{PENDAHULUAN}

Pembelajaran merupakan usaha sadar dari seorang guru untuk membelajarkan siswanya dalam rangka mencapai tujuan yang diharapkan, sebagai produk interaksi berkelanjutan antara pengembangan dan pengalaman hidup [I]. Interaksi siswa dalam pembelajaran sangat diperlukan karena melalui interaksi suasana belajar akan menjadi lebih aktif. Dalam proses pembelajaran perlu adanya pendekatan dalam pencapaian tujuan belajar tersebut, karena pendekatan pada hakekatnya diartikan sebagai titik tolak atau sudut pandang terhadap proses pembelajaran. Perspektif atau pendekatan pembelajaran berkembang dan berubah dari waktu ke waktu. Perspektif pembelajaran saat ini, perkembangannya tidak terlepas dari perspektif pembelajaran sebelumnya.

Efektif tidaknya suatu proses pembelajaran tergantung pada beberapa faktor, diantara faktor tersebut adalah motivasi belajar dan pengalaman belajar siswa. Hal ini berarti bahwa pengetahuan dibentuk menjadi pemahaman individual melalui sebuah interaksi antara siswa dengan lingkungan dan orang lain $[2]$.

Keberhasilan sebuah proses pembelajaran salah satunya ditentukan oleh proses pemerolehan dan pembentukan konsep yang terjadi pada diri siswa. Pemerolehan dan pembentukan konsep pada siswa dapat dipercepat dengan berbagai cara salah satunya dengan menggunakan media pembelajaran. Selain itu, keberhasilan sebuah proses pembelajaran juga ditentukan oleh model atau pendekatan pembelajaran yang digunakan. Karakteristik materi pelajaran perlu diperhatikan, sebagai contoh materi Gaya Lorentz pada pelajaran Fisika kelas XII SMA merupakan materi yang bersifat abstrak, sehingga dalam penyajian materi tersebut perlu dilakukan pendekatan tertentu, salah satunya dengan memanfaatkan penggunaan media alat peraga.

Pada kenyataannya guru sering mengesampingkan penggunaan media pembelajaran. Beberapa alasan yang terungkap dikarenakan dalam penggunaan media butuh waktu, tenaga dan biaya untuk mempersiapkannya. Di samping itu masih seringnya guru menggunakan model pembelajaan konvensional yang terfokus pada guru (teacher centre), sementara paradigma pendidikan saat ini siswa menjadi pusat dari pembelajaran tersebut (student centre). Akibat dari hal tersebut pencapaian hasil belajar siswa tidak optimal.

\section{Media Pembelajaran}

National Education Associaton, menyebutkan bahwa media pembelajaran adalah sarana komunikasi dalam bentuk cetak maupun pandang-dengar, termasuk teknologi perangkat keras. Sementara Schramm, mengemukakan bahwa media pembelajaran adalah teknologi pembawa pesan yang dapat dimanfaatkan untuk keperluan pembelajaran [3].

Dari pendapat-pendapat tersebut di atas dapat dinyatakan bahwa media pembelajaran adalah segala sesuatu yang dapat menyalurkan pesan, dapat merangsang pikiran, perasaan, dan kemauan peserta didik sehingga dapat mendorong terciptanya proses belajar pada diri peserta didik. 


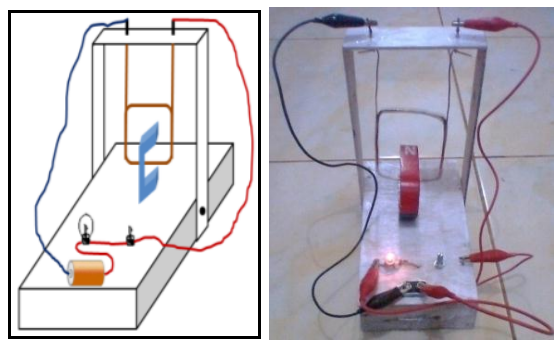

Gambar I. Desain Model alat peraga

Bandul magnetik yang didesain sebagai media pembelajaran digunakan untuk menyampaikan sejumlah informasi kepada siswa dengan maksud membentuk sebuah konsep dalam alam berpikir siswa. Model bandul magnetik ini terdiri atas magnet $\mathrm{U}$, ayunan kumparan, potensiometer, lampu dan sumber arus listrik searah yang dihubungkan dengan kawat penghantar.

\section{Pembelajaran Inquiri}

Pembelajaran inquiry merupakan suatu kegiatan pembelajaran yang melibatkan peserta didik secara maksimal pada seluruh kemampuan peserta didik untuk mencari dan meyelidiki secara sistemik, kritis, logis, dan analisis suatu konsep dalam pembelajaran sehingga peserta didik dapat merumuskan sendiri penemuannya [4].

Atas dasar definisi di atas, maka pembelajaran inquiry dapat diartikan sebagai sebuah model pembelajaran dimana guru berkapasitas mengarahkan siswa untuk mampu menyadari apa yang telah didapatkan selama proses pembelajaran, mampu berpikir dan terlibat langsung dalam kegiatan pembelajaran serta memproses pengalaman belajar tersebut menjadi suatu pengetahuan yang bermakna dalam kehidupan nyata. Pada kegiatan pembelajaran ini pembentukan konsep di diri siswa dilakukan oleh siswa sendiri, sedangkan guru hanya berperan untuk mengarahkan pemikiran siswa dengan pertanyaan yang bersifat menuntun (guide question) sehingga siswa dapat mengkonstruksi sebuah konsep dalam alam pikirannya.

Tahapan-tahapan (sintaks) model pembelajaran inquiry dilakukan dengan urutan seperti pada tabel berikut [5].

\begin{tabular}{|c|c|c|}
\hline No & $\begin{array}{l}\text { Level of } \\
\text { Inquiry }\end{array}$ & Tujuan Pembelajaran yang Utama \\
\hline $\mathrm{I}$ & $\begin{array}{l}\text { Discover } \\
\text { Learning }\end{array}$ & $\begin{array}{l}\text { Peserta didik mengembangkan konsep } \\
\text { berdasarkan pengalaman langsung (focus } \\
\text { pada keterlibatan aktif dalam membangun } \\
\text { pengetahuan) }\end{array}$ \\
\hline 2 & $\begin{array}{l}\text { Interactive } \\
\text { demonstrati } \\
\text { on }\end{array}$ & $\begin{array}{l}\text { Peserta didik terlibat dalam penjelasan dan } \\
\text { predisksi - memungkinkan guru untuk } \\
\text { mengidentifikasi dan menghadapi konsepsi } \\
\text { alternative (menangani pengetahuan } \\
\text { sebelumnya) }\end{array}$ \\
\hline 3 & $\begin{array}{l}\text { Inquiry } \\
\text { lesson }\end{array}$ & $\begin{array}{l}\text { Peserta didik mengidentifikasi dan atau } \\
\text { hubungan ilmiah (kerja sama yang } \\
\text { digunakan untuk membangun pengetahuan } \\
\text { yang lebih terperinci) }\end{array}$ \\
\hline 4 & $\begin{array}{l}\text { Inquiry } \\
\text { laboratory }\end{array}$ & $\begin{array}{l}\text { Peserta didik membuat hokum empiris } \\
\text { berdasarkan pengukuran variable ( kerja } \\
\text { laboratif yang digunakan untuk } \\
\text { membangun pengetahuan yang lebih } \\
\text { terperinci }\end{array}$ \\
\hline 5 & $\begin{array}{l}\text { Real-World } \\
\text { applications }\end{array}$ & $\begin{array}{l}\text { Peserta didik memecahkan masalah yang } \\
\text { berkaitan dengan situasi otentik saat } \\
\text { menggunakan pendekatan berbasis masalah } \\
\text { dan berbasis proyek }\end{array}$ \\
\hline
\end{tabular}

6 Hypothetica Peserta didik menghasilkan hipotesis dan 1 Inquiry menguji hipotesis/ ekplanasi untuk fenomena yang diamati (pengalaman bentuksains yang lebih realistis)

\section{Discovery Learning}

Fokus kegiatan ini bukanlah untuk menemukan aplikasi pengetahuan, melainkan pada membangun konsep dan pengetahuan berdasarkan pengalaman belajar peserta didik. Dengan demikian, discovey learning menggunakan refleksi sebagai kunci untuk memahami konsep. Guru memperkenalkan sebuah pengalaman sedemikian rupa untuk meningkatkan relevansi atau maknanya, menggunakan serangkaian pertanyaan selama atau setelah pengalaman untuk membimbing siswa mencapai kesimpulan tertentu, dan memberi pertanyaan kepada siswa untuk mendiskusikan langsung yang berfokus pada masalah atau kontradiksi yang nyata. Dengan menggunakan penalaran induktif, peserta didik membangun hubungan atau prinsip sederhana berdasarkan hasil pengamatan yang dipandu guru. Dimana guru memberikan serangkaian pertanyaan yang bertujuan untuk memancing siswa dalam mengumpulkan informasi. Sementara siswa ikut dilibatkan dalam memberi respon positif terhadap masalah yang dikemukakan dan mengungkapkan tanggapan sebagai ide awalnya.

2. Interactive Demonstration

Pada tahapan ini seorang guru yang mendemonstrasikan peralatan dan kemudian mengajukan pertanyaan menyelidik yang bersifat prediksi terhadap sesuatu yang mungkin terjadi. Guru bertugas melakukan demonstrasi, mengembangkan dan mengajukan pertanyaan menyelidik, memunculkan tanggapan, meminta penjelasan lebih lanjut, dan membantu peserta didik mencapai kesimpulan berdasarkan bukti. Dimana guru memberikan pertanyaan pengarah sehingga siswa mampu mengidentifikasi dan merumuskan hipotesis. Keterlibatan siswa dalam tahap ini untuk melakukan pengamatan terhadap permasalahan yang diberikan, merumuskan masalah, mengidentifikasi masalah, membuat hipotesis, dan merancang sebuah bentuk eksperimen, serta mengembangkannya untuk pemecahan masalah-masalah yang kontekstual.

3. Inquiry Lesson

Inquiry Lesson serupa dengan demonstrasi interaktif. Namun, ada beberapa perbedaan penting. Dalam Inquiry Lesson, penekanan secara halus beralih ke bentuk percobaan ilmiah yang lebih kompleks. Guru masih berperan memberikan panduan, fasilitator, dan menggugah pertanyaan. Bimbingan diberikan secara tidak langsung dengan menggunakan strategi tanya jawab yang tepat. Guru memfasilitasi peserta didik untuk merencanakan percobaan sendiri, mengidentifikasi dan mengendalikan variabel. Guru secara eksplisit dengan memberikan panduan tentang saintifik proses melalui pertanyaan pembimbing. Guru memodelkan proses intelektual mendasar dan menjelaskan pemahaman mendasar tentang saintifik inkuiri sementara peserta didik belajar dengan mengamati, mendengarkan, dan menanggapi pertanyaan. Proses pembelajaran pada level ini guru mengajak siswa untuk "berpikir keras" (think aloud). Pendekatan ini akan lebih membantu siswa. 
4. Inquiry Laboratory

Inquiry Lab adalah kegiatan membimbing peserta didik lebih mandiri dalam mengembangkan dan melaksanakan rencana eksperimen dan mengumpulkan data yang sesuai. Data ini kemudian dianalisis untuk menemukan hukum hubungan yang tepat antara variabel. Pendekatan Inquiry $L a b$ melibatkan aktivitas peserta didik sebagai berikut:

(a) Didorong oleh pertanyaan yang membutuhkan keterlibatan intelektual berkelanjutan dengan menggunakan kemampuan berpikir tingkat tinggi untuk pemikiran independen;

(b) Fokuskan kegiatan peserta didik dalam pengumpulan dan data untuk menemukan konsep, prinsip, atau hukum baru yang bergerak dari konkret menjadi abstrak;

(c) Meminta peserta didik untuk membuat desain eksperimental mereka sendiri; mewajibkan peserta didik untuk mengidentifikasi, membedakan, dan mengendalikan variabel-variabel penting dan dependen; dan mendorong peserta didik memiliki keterampilan dan kemampuan saintifik inkuiri;

(d) Biasanya memungkinkan peserta didik belajar dari kesalahan prosedur; memberikan waktu dan kesempatan bagi peserta didik untuk membuat dan memperbaiki kesalahannya;

(e) Menggunakan prosedur yang jauh lebih konsisten dengan praktik ilmiah otentik;

5. Real-world Applications

Dalam pembelajaran level ini siswa menerapkan apa yang telah mereka pelajari melalui pengalaman ke situasi baru. Siswa menemukan jawaban yang berkaitan dengan masalah otentik saat bekerja secara individu atau dalam kelompok kooperatif dan kolaboratif dengan menggunakan pendekatan berbasis masalah \& berbasis proyek. Kegiatan ini mengarahkan siswa bagaimana sebenarnya para ilmuwan dalam memecahkan masalah. Dalam pembelajaran berbasis masalah atau berbasis proyek akan berfungsi untuk melatih siswa dalam menggunakan konsep, prinsip, dan hukum dalam memecahkan masalah sehari-hari/kontekstual.

6. Hypothetical Inquiry

Pada level ini guru memberikan kesempatan kepada siswa untuk mengajukan hipotesis dan pengujian. Hypothetical Inquiry perlu dibedakan dari membuat prediksi. Prediksi adalah pernyataan tentang apa yang akan terjadi mengingat satu set kondisi awal. Prediksinya tidak memiliki kekuatan penjelasan apa pun, meskipun mungkin deduksi logis berasal dari hukum atau pengalaman. Hipotesis adalah penjelasan sementara yang dapat diuji secara menyeluruh, dan hal itu dapat mengarahkan penyelidikan lebih lanjut. Hypothetical Inquiry berhubungan dengan memberikan dan menguji penjelasan (biasanya "bagaimana", bukan "mengapa"), untuk menjelaskan hukum atau pengamatan tertentu.

Hasil belajar merupakan salah satu tolok ukur keberhasilan proses pembelajaran. Hasil belajar juga merupakan indikator tercapai tidaknya tujuan pembelajaran yang telah ditetapkan, sehingga hasil belajar menjadi bagian tidak terpisahkan dari proses pembelajaran. Jika dikaji kembali tentang hakikat sains, maka pada dasarnya hasil belajar sains mencakup tiga aspek kompetensi yaitu aspek pengetahuan (kognitif), sikap (afektif), dan keterampilan (psikomotor). Namun pada penelitian ini yang dimaksud dengan hasil belajar adalah hasil yang diperoleh siswa melalui serangkaian tes kognitif yang dilakukan setelah proses pembelajaran dilaksanakan.

\section{METODE PENELITIAN}

Penelitian ini berupa tindakan kelas yang dilaksanakan pada siswa kelas XII IPA I SMAN 5 Kota Bima sebagai subjek penelitiannya. Waktu pelaskanaan dilakukan pada semester ganjil tahun pelajaran 2017/2018, dengan pokok materi gaya Lorentz. Pelasanaan penelitian direncanakan mulai bulan Juli sampai dengan September 2017. Objek penelitian yang diamati adalah hasil belajar kognitif siswa dengan target ketercapaian nilai ketuntasan klasikal sebesar $75 \%$, serta respon siswa terhadap pembelajaran.

Data yang dikumpulkan berupa data kualitatif dan data kuantitatif. Data kualitatif berupa deskripsi perencanaan, penyusunan instrumen, tindakan observasi/evaluasi, dan refleksi. Sedangkan data kuantitatif berupa prestasi belajar siswa setelah melakukan tes tertulis. Data mengenai proses belajar siswa dalam pembelajaran dikumpulkan melalui observasi. Instrumen yang dipakai dalam pengumpulan data ini adalah lembar observasi yang berisikan indikator perilaku siswa. Pengamatan proses belajar/aktivitas belajar siswa dilaksanakan pada saat pembelajaran di kelas. Adapun indikator perilaku siswa tersebut adalah; (a) antusiasme dalam mengikuti kegiatan pembelajaran; (b) interaksi siswa dan guru serta interaksi antarsiswa; (c) aktivitas siswa dalam diskusi kelompok; (d) partisipasi siswa dalam menyimpulkan materi ajar.

Dalam penelitian ini dilakukan dengan 2 (dua) siklus dengan tiap siklus terdiri dari perencanaan, pelaksanaan, pengamatan dan refleksi.

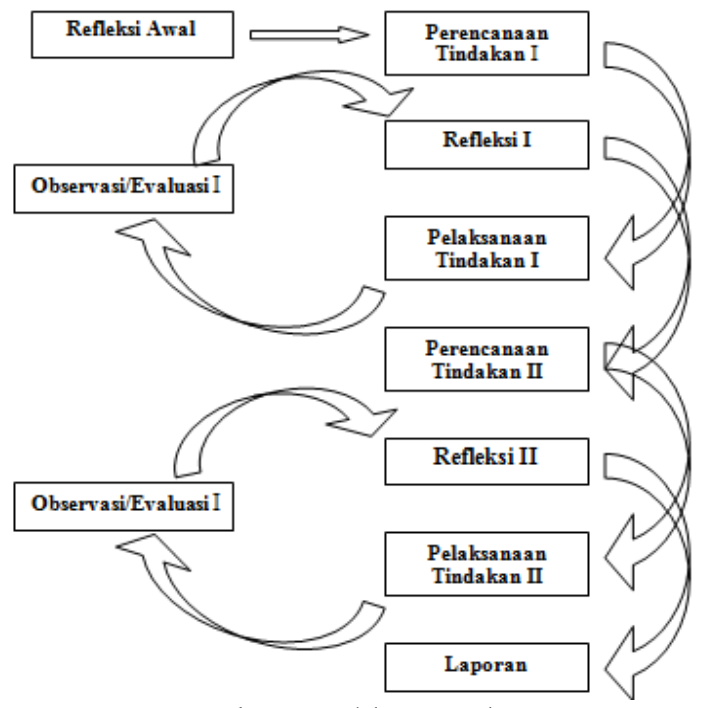

Gambar 2. Siklus Penelitian

Pada kegiatan pembelajaran dilakukan pengamatan terhadap proses tersebut, hal ini digunakan untuk kegiatan refleksi guna perbaikan proses pembelajaran pada siklus selanjutnya. Setiap akhir silkus dilakukan serangkaian tes kognitif dan angket respon siswa, hal ini dilakukan untuk mengetahui seberapa besar peningkatan hasil belajar yang dicapai. 


\section{Metode Pengumpulan dan Analisi Data}

Data yang diperoleh dari siklus tersebut dianalisis secara deskriptif. Aktifitas proses belajar siswa ditentukan berdasarkan indikator proses dengan kriteria [6]:

\begin{tabular}{|l|l|l|}
\hline \multicolumn{2}{|c|}{ Kriteria } & \multicolumn{1}{c|}{ Penggolongan } \\
\hline $\mathrm{Mi}+1,5 \mathrm{Sdi} \leq \bar{M}$ & $40 \leq \bar{M}$ & sangat aktif \\
\hline $\mathrm{Mi}+0,5 \mathrm{Sdi} \leq \bar{M}<\mathrm{Mi}+1,5 \mathrm{Sdi}$ & $32 \leq \bar{M}<40$ & Aktif \\
\hline $\mathrm{Mi}-0,5 \mathrm{Sdi} \leq \bar{M}<\mathrm{Mi}+0,5 \mathrm{Sdi}$ & $24 \leq \bar{M}<32$ & cukup aktif \\
\hline $\mathrm{Mi}-1,5 \mathrm{Sdi} \leq \bar{M}<\mathrm{Mi}-0,5 \mathrm{Sdi}$ & $16 \leq \bar{M}<24$ & kurang aktif \\
\hline $\bar{M}<\mathrm{Mi}-1,5 \mathrm{Sdi}$ & $\bar{M}<16$ & sangat kurang aktif \\
\hline
\end{tabular}

(perhitungan indikator berdasarkan pendapat Zainul dan Nasoetion)

Rata-rata proses belajar yang diperoleh siswa dalam satu siklus $(\bar{M})$ selanjutnya disesuaikan dengan penggolongan di atas, sehingga dapat ditentukan tingkat proses belajar siswa selama proses pembelajaran. Dimana Sdi sebagai standar deviasi. Kriteria keberhasilan untuk setiap siklus adalah proses belajar siswa minimal tergolong aktif.

Hasil belajar dianalisis berdasarkan capaian nilai ketuntasan hasil belajar minimal sebesar 65 dengan memanfaatkan nilai ketuntasan klasikal. Untuk menentukan ketuntasan belajar menurut Zainul dan Nasoetion digunakan rumusan berikut [7]:

\section{$K B=\frac{\text { banyaknyasiswayangmemperolehnilai } \geq 65}{\text { banyalnowa }} \times 100 \%$}

Kriteria keberhasilan untuk setiap siklus adalah ketuntasan belajar minimal 70\%. Jika kriteria ini belum tercapai maka akan dilakukan perbaikan pada siklus 2 dan selanjutnya. Di samping itu dilakukan pengambilan data tanggapan siswa dengan menggunakan angket.

Data tanggapan siswa dianalisis secara deskriptif untuk mengetahui tanggapan siswa terhadap model pembelajaran yang digunakan. Analisis ini didasarkan atas rata-rata kelas dari skor tanggapan siswa (P), Mi dan Sdi. Rata-rata kelas dari skor tanggapan siswa dihitung dengan menjumlahkan skor tanggapan seluruh siswa dibagi dengan jumlah seluruh siswa.

Angket yang digunakan dalam penelitian ini terdiri dari 25 item yang penskorannya menggunakan skala Likert, yakni setiap item mempunyai skor maksimal 4 dan minimal I. Dengan demikian mean ideal dan standar deviasi idealnya masing-masing adalah 50 dan I2,5. Berdasarkan Mi dan sdi dari skor tanggapan siswa, maka penggolongan tanggapan siswa adalah sebagai berikut.

\begin{tabular}{|l|l|l|}
\hline \multicolumn{2}{|c|}{ Kritenia } & \multicolumn{1}{|c|}{ Penggolongan } \\
\hline $\mathrm{Mi}+1,5 \mathrm{Sdi} \leq \mathrm{P}$ & $68,7 \leq \mathrm{P}$ & sangat positif \\
\hline $\mathrm{Mi}+0,5 \mathrm{Sdi} \leq \mathrm{P}<\mathrm{Mi}+1,5 \mathrm{Sdi}$ & $56,2 \leq \mathrm{P}<68,7$ & Positif \\
\hline $\mathrm{Mi}-0,5 \mathrm{Sdi} \leq \mathrm{P}<\mathrm{Mi}+0,5 \mathrm{Sdi}$ & $43,7 \leq \mathrm{P}<56,2$ & cukukp positif \\
\hline $\mathrm{Mi}-1,5 \mathrm{Sdi} \leq \mathrm{P}<\mathrm{Mi}-0,5 \mathrm{Sdi}$ & $31,2 \leq \mathrm{P}<43,7$ & kurang positif \\
\hline $\mathrm{P}<\mathrm{Mi}-1,5$ Sdi & $\mathrm{P}<31,2$ & sangat kurang positif \\
\hline
\end{tabular}

Skor rata-rata tanggapan siswa (P) yang diperoleh, selanjutnya dikategorikan sesuai dengan penggolongan di atas. Kriteria keberhasilan dalam penelitian ini adalah minimal tanggapan siswa tergolong positif.

\section{HASIL DAN PEMBAHASAN}

Hasil penelitian mengenai proses belajar, prestasi belajar, dan tanggapan siswa dirangkumkan dalam tabel berikut :

\begin{tabular}{|l|l|l|l|l|l|l|}
\hline \multirow{2}{*}{ SIKLUS } & \multicolumn{2}{|c|}{ PROSES BELAJAR } & \multicolumn{2}{c|}{ HASL BELAJAR } & \multicolumn{2}{c|}{ TANGGAPAN SISWA } \\
\cline { 2 - 6 } & RERATA & KATAGORI & RERATA & KB (\%) & RERATA & KATAGORI \\
\hline SIKLUS I & 31 & Cukup Aktif & 60,45 & 50,0 & 72,5 & $\begin{array}{l}\text { SANGAT } \\
\text { POSITIF }\end{array}$ \\
\hline SIKLUS II & 34 & Aktif & 66,59 & 77,3 & & \\
\hline
\end{tabular}

Berdasarkan hasil observasi proses belajar siswa tergolong dalam kategori aktif dan telah memenuhi kriteria keberhasilan yang ditetapkan. Pada awal pertemuan, umumnya siswa belum siap dengan penggunaan media peraga bandul magnetik pada model pembelajaran inquiry ini. Pada pertemuan kedua, siswa sudah sangat siap dengan pembelajaran yang dilaksanakan, perhatian siswa lebih terfokus yang menunjukkan, proses belajar siswa sudah sangat baik (aktif) sesuai dengan parameter aktivitas yang diamati.

Antusiasme siswa dalam mengikuti pembelajaran dapat dilihat dari animo siswa untuk menggunakan media peraga bandul magnetik. Interaksi siswa dengan guru dan antar temannya berlangsung dengan sangat aktif. Mereka berani mengajukan dan menjawab permasalahan, serta memperbaiki kesalahan temannya dengan argumentasi yang mereka pahami lewat percobaan yang dilakuka. Proses belajar siswa dalam diskusi, baik diskusi kelompok maupun kelas sangat baik.

Hasil belajar yang dicapai oleh siswa pada Siklus I belum sesuai dengan yang diharapkan. Masih rendahnya prestasi belajar ini disebabkan oleh ketuntasan pembahasan materinya relatif kurang. Temuan dari hasil belajar siswa pada Siklus I adalah jawaban siswa masih tergolong dalam tingkat berpikir rendah (lower order thinking). Pada saat diskusi kelompok, guru lebih sering memerankan diri sebagai pengajar yang berusaha menuangkan seluruh pengetahuan ke pikiran siswa. Dalam hal ini peran guru sebagai fasilitator pembelajaran masih perlu diperbaiki. Hasil belajar yang diperoleh ini menunjukkan bahwa siswa belajar dengan cara menghafal (verbalisme) dan lemahnya tingkat analisis siswa.

Pada Siklus II, terjadi peningkatan hasil belajar siswa dibandingkan dengan yang diperoleh pada Siklus I dan telah memenuhi kriteria keberhasilan penelitian ini. Peningkatan ini tidak lepas dari penggunaan media peraga bandul magnetik pada model pembelajaran inquiry. Dalam hal ini media berperan untuk mengkongkritkan materi-materi yang bersifat abstrak. Selain faktor media yang digunakan, hal ini tidak terlepas dari peran guru sebagai fasilitator pembelajaran pada saat diskusi kelompok maupun kelas. Saat berdiskusi guru memberikan pertanyaan-pertanyaan pancingan untuk melatih siswa berpikir kritis. Secara umum tingkat berpikir siswa sudah meningkat menjadi tingkat berpikir tinggi (higher order thinking). Hal ini dapat dilihat dari jawaban siswa di mana mereka selain mampu menjawab soal dengan tingkat pemahaman dan penerapan juga soal dengan tingkat argumentasi dan analisis. Untuk soal dengan tingkat argumentasi dan analisis, sebagian besar siswa dapat menjawab dengan benar.

Pendapat siswa terhadap penggunaan media peraga bandul magnetik pada model pembelajaran inquiry diperoleh dengan mengedarkan angket di akhir tindakan. Hasil yang diperoleh dari tanggapan siswa terhadap pembelajaran yang diimplementasikan tergolong sangat positif dan telah memenuhi kriteria keberhasilan yang ditetapkan. Siswa umumnya 
memberikan apresiasi positif terhadap pembelajaran yang diimplementasikan. Misalnya, senang belajar Fisika, pelajaran Fisika mudah dipahami, serta memahami aspek mikroskopik Fisika. Kebanyakan siswa menyatakan bahwa pembelajaran model ini sangat baik diterapkan pada pembelajaran Fisika. Mereka sangat tertarik untuk berinteraksi langsung dengan media. Penerapan pembelajaran ini dapat memberikan pengalaman belajar Fisika yang baru sehingga sangat membantu memahami Fisika. Siswa mengharapkan agar model pembelajaran ini terus dioptimalkan dan terus diterapkan pada pembelajaran Fisika. Meskipun demikian, beberapa saran yang disampaikan oleh siswa adalah sebagai berikut. I) Media yang digunakan kurang variasi. 2) Waktu diskusi lebih lama yang diselingi oleh penjelasan guru. 3) Peran guru untuk mengatasi permasalahan yang belum terpecahkan oleh siswa lebih ditingkatkan.

Temuan lain yang diperoleh dalam penelitian ini berupa kelebihan penggunaan media bandul magnetik sebagai media demonstrasi dalam pembelajaran Fisika. Kelebihan tersebut adalah :

I. Dapat menunjukan fenomena terjadinya gaya Lorentz

2. Dapat divariasi dengan beberapa variabel, yaitu besar dan arah arus listrik, serta besar dan arah medan magnet

3. Relatif mudah untuk dibuat dan digunakan

Di samping memiliki kelebihan, alat peraga ini juga memiliki kelemahan. Kelemahan tersebut adalah arah simpangan ayunan tidak dapat dilihat dari jauh, namun dapat disiasati dengan pemanfaatkan fasilitas video.

Secara keseluruhan meningkatnya hasil belajar siswa dengan penggunaan media dengan dikolaborasikan pada pembelajaran inquiry dikarenakan pembelajaran inquiry memiliki karakteristik untuk membiasakan siswa mengkontrusi pengetahuannya sendiri, terlebih lagi pembelajaran yang dilakukan selalu memposisikan siswa untuk terlibat secara langsung dalam setiap tahapan pembelajarannya. Dengan demikian pengalaman yang dialami oleh siswa lebih melekat pada memori siswa.

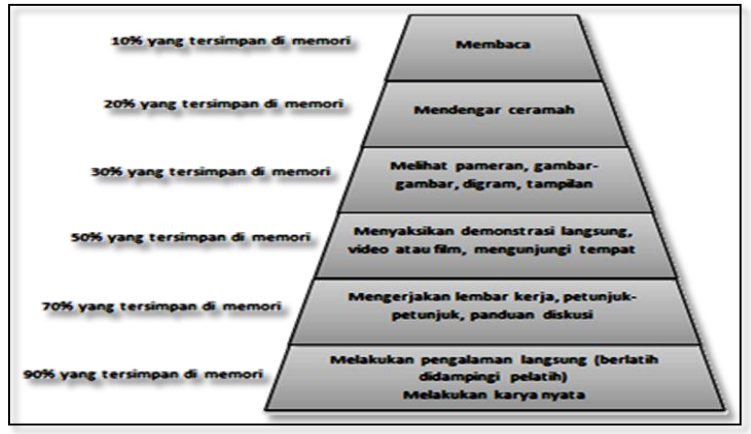

Gambar 3. Bagan Teori Learning Pyramid

Hal ini sesuai dengan teori learning pyramid (Setyawan, 2013) yang mengungkapkan bahwa dengan menyaksikan dan mengalami langsung proses pembelajaran maka memori setiap individu akan terisi $50 \%$, sementara jika hanya melihat memori yang terisi $30 \%$, dengan mendengar memori yang terisi $20 \%$, dan dengan membaca memori yang terisi $10 \%$.

Pencapaian hasil penelitian ini didukung oleh pendapat Gerlac dan Ely (dalam Setiawan, 20II) yang menegaskan bahwa terdapat tiga keistemewaan yang dimiliki media pengajaran yaitu : (I) media memiliki kemampuan untuk menangkap, menyimpan dan menampilkan kembali suatu objek atau kejadian, (2) media memiliki kemampuan untuk menampilkan kembali objek atau kejadian dengan berbagai macam cara disesuaikan dengan keperluan, dan (3) media mempunyai kemampuan untuk menampilkan sesuatu objek atau kejadian yang mengandung makna. Pendapat lain juga disampaikan oleh Hamalik, 1986 (dalam Setiawan, 201I) mengemukakan bahwa pemakaian media pembelajaran dalam proses belajar mengajar dapat membangkitkan keinginan dan minat yang baru pada diri siswa, membangkitkan motivasi dan rangsangan dalam kegiatan pembelajaran dan bahkan membawa pengaruh-pengaruh psikologis terhadap siswa.

Penggunaan media pembelajaran akan sangat membantu efektifitas proses pembelajaran serta penyampaian pesan dan isi pelajaran sehingga dapat membantu siswa meningkatkan pemahaman karena menyajikan informasi secara menarik dan terpercaya. Selain itu media pembelajaran juga dapat memudahkan penafsiran data dan memadatkan informasi. Untuk tujuan tersebut maka seorang pendidik perlu memiliki sebuah media pembelajaran yang memadai, agar bahan ajar dapat diserap peserta didik dengan sebaik-baiknya.

\section{KESIMPULAN}

Sesuai dengan hasil dan pembahasan di atas bahwa implementasi pembelajaran inquiry dengan menggunakan media peraga bandul magnetik dapat disimpulkan sebagai berikut.

I) Penggunaan media peraga bandul magnetik pada model pembelajaran inquiry dapat meningkatkan hasil belajar Fisika siswa Kelas XII SMA Negeri 5 Kota Bima.

2) Implementasi pembelajaran inquiry dengan memanfaatkan media peraga bandul magnetik direspon sangat positif oleh siswa Kelas XII SMA Negeri 5 Kota Bima. Mereka mengharapkan pembelajaran ini terus diterapkan dan dioptimalkan.

\section{SARAN}

Berdasarkan temuan-temuan selama penelitian ini beberapa saran kepada guru Fisika untuk menerapkan metode pembelajaran ini terutama pada aspek kualitatif yang bersifat abstrak, selain itu guru harus dapat mengoptimalkan waktu dan tidak terlepas dari koridor sintaks pembelajaran inquiry. Oleh karena itu, pemilihan media peraga yang tepat dalam pembelajaran sangat membantu siswa untuk memahami Fisika.

\section{DAFTAR PUSTAKA}

[I] Trianto, (2009), Mendesain Model Pembelajaran Inovatif Progresif, Kencana, Jakarta

[2] Winataputra, Udin S, (2008), Teori Belajar dan Pembelajaran, Universitas Terbuka, Jakarta.

[3] Sudrajad, Akhmad, (2009), Media Pembelajaran, (Online); http://akhmadsudrajat. wordpress.com/2008/0I/I2/media-pembelajaran/, diakses tanggal 27 Januari 2017

[4] Kemendikbud (2015), Model-model Pembelajaran (Diktat bahan Pelatihan KI3), Direktorat Pembinaan SMA, Kementerian Pendidikan dan Kebudayaan, Jakarta 
[5] Kaniawati, Ida, (2017), Konsep dan Level Inquiry (Hand Out bahan Pelatihan Pengembangan Pembelajaran $I P A)$, PPPPTK IPA, Bandung

[6] Setiawan, Bambang, (2012), Pemanfaatan Multimedia pada Pembelajaran Kooperatif sebagai Upaya Meningkatkan Prestasi Belajar Fisika, Laporan PTK, SMA Negeri 5 Kota Bima

[7] Setyawan, Sigit, 2013, Nyalakan Kelasmu, PT Gramedia Widiasarana Indonesia, Jakarta. 